\title{
Comparison of responses of human melanoma cell lines to MEK and BRAF inhibitors
}

\author{
Clare J. Stones ${ }^{1,2}$, Ji Eun Kim ${ }^{2}$, Wayne R. Joseph ${ }^{2}$, Euphemia Leung ${ }^{2}$, Elaine S. Marshall ${ }^{2}$, \\ Graeme J. Finlay ${ }^{2}$, Andrew N. Shelling ${ }^{1}$ and Bruce C. Baguley ${ }^{2 *}$ \\ Department of Obstetrics and Gynaecology, The University of Auckland, Auckland, New Zealand \\ ${ }^{2}$ Auckland Cancer Society Research Centre, The University of Auckland, Auckland, New Zealand
}

Edited by:

Mike Eccles, University of Otago,

New Zealand

Reviewed by:

Josh Waterfall, National Institutes of Health, USA

Paola Parrella, IRCCS Casa Sollievo della Sofferenza, Italy

*Correspondence:

Bruce C. Baguley, Auckland Cancer Society Research Centre, The

University of Auckland, Private Bag 92019, Auckland 1142, New Zealand. e-mail: b.baguley@auckland.ac.nz
The NRAS and BRAF genes are frequently mutated in melanoma, suggesting that the NRAS-BRAF-MEK-ERK signaling pathway is an important target for therapy. Two classes of drugs, one targeting activated BRAF and one targeting MEK, are currently undergoing clinical evaluation. We have analysed the NRAS and BRAF mutational status of a series of 44 early passage lines developed from New Zealand patients with metastatic melanoma. $41 \%$ of the lines analysed had BRAF mutations, $23 \%$ had NRAS mutations, and $36 \%$ had neither. We then determined $I C_{50}$ values (drug concentrations for $50 \%$ growth inhibition) for $\mathrm{Cl}-1040$, a commonly used inhibitor of MEK kinase; trametinib, a clinical agent targeting MEK kinase; and vemurafenib, an inhibitor of mutant BRAF kinase. Cell lines with activating BRAF mutations were significantly more sensitive to vemurafenib than lines with NRAS mutations or lines lacking either mutation $(p<0.001)$. IC $C_{50}$ values for $\mathrm{Cl}-1040$ and trametinib were strongly correlated $(r=0.98)$ with trametinib showing $\sim 100$-fold greater potency. Cell lines sensitive to vemurafenib were also sensitive to $\mathrm{Cl}-1040$ and trametinib, but there was no relationship between $\mathrm{IC}_{50}$ values and NRAS mutation status. A small number of lines lacking a BRAF mutation were sensitive to $\mathrm{Cl}-1040$ but resistant to vemurafenib. We used western blotting to investigate the effect on ERK phosphorylation of $\mathrm{Cl}-1040$ in four lines, of vemurafenib in two lines and of trametinib in two lines. The results support the view that MEK inhibitors might be combined with BRAF inhibitors in the treatment of melanomas with activated BRAF. The high sensitivity to trametinib of some lines with wildtype BRAF status also suggests that MEK inhibitors could have a therapeutic effect against some melanomas as single agents.

Keywords: mitogen-activated protein kinase pathway, melanoma treatment, NRAS, BRAF, MEK, ERK, vemurafenib, trametinib

\section{INTRODUCTION}

Malignant melanoma is an important public health issue, particularly in Australia and New Zealand where the incidence rates for melanoma are very high (Coory et al., 2006; Liang et al., 2010). While early stage melanoma can usually be treated successfully by surgery, metastatic melanoma has a poor survival rate and is highly resistant to conventional cytotoxic chemotherapy. Activating mutations in the BRAF gene have been reported in $40-70 \%$ of melanomas and activating mutations in the NRAS gene in another 10-30\% (Davies et al., 2002). There is considerable interest in developing therapies targeting this pathway, and clinical trials of drugs such as vemurafenib (PLX4032), which target mutant BRAF protein, have provided very promising results with $81 \%$ of patients with BRAF mutant melanoma having clinical responses in a Phase I trial (Flaherty et al., 2010). Since preclinical studies indicate that BRAF inhibitors are ineffective in melanomas lacking BRAF mutations and may even enhance growth (Hatzivassiliou et al., 2012), advanced clinical trials of vemurafenib and other BRAF inhibitors are being carried out specifically in patients whose melanomas contain BRAF mutations (Solit et al., 2006; Flaherty et al., 2010).
Resistance to BRAF inhibitors develops relatively rapidly because of BRAF-independent activation of MEK and ERK (Johannessen et al., 2010) and other chemotherapeutic approaches will be necessary, both for melanomas lacking mutant $B R A F$ and for melanomas that have developed resistance. The MEK protein, which functions downstream from BRAF, is thus a further potential target (Johannessen et al., 2010). Preclinical studies with MEK inhibitors reported that BRAF mutant melanoma cells growing both in vitro and in vivo as xenografts were more responsive to MEK inhibition than cell lines with wild type BRAF status (Davies et al., 2002; Solit et al., 2006). Furthermore, the new MEK inhibitor trametinib (GSK1120212) has shown evidence of clinical efficacy against melanoma (Falchook et al., 2012), and has shown survival benefits in phase III trial (Flaherty et al., 2012).

In this study, we have characterized the BRAF and NRAS mutation status of a series of melanoma cell lines developed from New Zealand patients with metastatic melanoma (Marshall et al., 1994; Charters et al., 2011; Kim et al., 2012). We determined the $\mathrm{IC}_{50}$ values of these cell lines to CI-1040, a MEK inhibitor that has been utilized extensively in preclinical studies (Sebolt-Leopold, 
2004) and compared these values to those for the mutant BRAF inhibitor vemurafenib. For a subset of cell lines we determined $\mathrm{IC}_{50}$ values for trametinib. Since rapid development of resistance (within hours) through up-regulation of MEK pathway signaling in the absence of BRAF mutations has been reported in melanoma cell lines (Friday et al., 2008), we have also measured in some cell lines the time-dependent effects of CI-1040 and vemurafenib on ERK phosphorylation.

\section{MATERIALS AND METHODS CELL LINES AND TISSUE CULTURE}

New Zealand Melanoma (NZM) cell lines were derived from metastatic tumors and developed at the Auckland Cancer Society Research Centre, New Zealand. The cell lines were maintained in $\alpha$-MEM medium (Invitrogen), supplemented with $5 \%$ foetal calf serum (Invitrogen), penicillin-streptomycin sulfate, and insulin-transferrin-selenite, in a $37^{\circ} \mathrm{C}$ incubator at $5 \% \mathrm{CO}_{2}$ and $\mathrm{O}_{2}$. The final concentrations of the supplements in media were 100 units/mL penicillin G, $100 \mu \mathrm{g} / \mathrm{mL}$ streptomycin sulfate, $5 \mu \mathrm{g} / \mathrm{mL}$ insulin, $5 \mu \mathrm{g} / \mathrm{mL}$ transferrin, and $5 \mathrm{ng} / \mathrm{mL}$ sodium selenite.

\section{GENOMIC PROFILING OF CELL LINES}

DNA from cell lines was sequenced for activating mutations in NRAS exon 2 and 3 and BRAF exon 11 and 15. DNA was extracted using phenol-chloroform-isoamyl alcohol. Exons of interest were amplified by PCR using Taq polymerase from Qiagen. The primer sequences for BRAF exon 15 and NRAS exon 2 and 3 were designed using DNA Star; the sequences are provided in Table 1. The primers for BRAF exon 11 are from a published source (Davies et al., 2002). The PCR conditions were as follows: an initial denaturation step at $95^{\circ} \mathrm{C}$ for $5 \mathrm{~min}$, followed by 30 cycles (BRAF exon 11) or 40 cycles (BRAF exon 15, NRAS exon 2 and 3 ) consisting of denaturation at $95^{\circ} \mathrm{C}$ for $1 \mathrm{~min}$, annealing at the appropriate temperature for $1 \mathrm{~min}$, extension at $72^{\circ} \mathrm{C}$ for $1 \mathrm{~min}$, followed by a final extension step at $72^{\circ} \mathrm{C}$ for $10 \mathrm{~min}$. The annealing temperatures for the PCR reactions were as follows: $60^{\circ} \mathrm{C}$ for $B R A F$ exon $11,56^{\circ} \mathrm{C}$ for $B R A F$ exon $15,58^{\circ} \mathrm{C}$ for NRAS exon 2, and $60^{\circ} \mathrm{C}$ for NRAS exon 3. Polyethylene glycol precipitation (Lis and Schleif, 1975) was used to purify the NRAS exon 2 and 3 and $B R A F$ exon 15 PCR products. Enzymatic digestion of unused PCR reaction ingredients by exonuclease 1 Affymetrix USB and shrimp alkaline phosphatase Affymetrix USB was used to purify $B R A F$ exon 11.

The PCR products were sequenced using thermal cycle sequencing, with Big Dye Terminator 3.1 chemistry (Applied Biosystems). The sequencing cycle conditions were as follows: an initial denaturation step at $95^{\circ} \mathrm{C}$ for $5 \mathrm{~min}$ followed by 25 amplification cycles of $1 \mathrm{~min}$ each of denaturation at $95^{\circ} \mathrm{C}$, annealing at $50^{\circ} \mathrm{C}$ for $5 \mathrm{~min}$, and primer extension at $60^{\circ} \mathrm{C}$ for $4 \mathrm{~min}$. The sequencing products were purified by ethanol precipitation and the sequences run on an Applied Biosystems 3130XL capillary sequencing machine at the Centre for Genomics and Proteomics, University of Auckland. Mutations were confirmed by sequencing in the opposite direction using separately amplified DNA.

\section{DETERMINATION OF IC $\mathbf{5}_{\mathbf{5 0}}$ VALUES}

The sensitivity of the cell lines to inhibitors was measured using a ${ }^{3}$ H-thymidine incorporation method (Marshall et al., 1992). Melanoma cells were plated in 96 well plates at 1000 cells per well and incubated overnight at $37^{\circ} \mathrm{C}$ at $5 \% \mathrm{CO}_{2}$ and $\mathrm{O}_{2}$. Drugs were added and plates incubated for 5 days at $37^{\circ} \mathrm{C}$ at $5 \% \mathrm{CO}_{2}$ and $\mathrm{O}_{2}$. ${ }^{3} \mathrm{H}$-thymidine $(0.04 \mu \mathrm{Ci} /$ well $)$, 5-fluorodeoxyuridine $(0.1 \mu \mathrm{M})$, and thymidine $(0.1 \mu \mathrm{M})$ were added $6 \mathrm{~h}$ before harvesting the cultures. To harvest, Pronase ( $2 \mathrm{mg} / \mathrm{mL}$ in $4 \mathrm{mM}$ EDTA in PBS) was added per well for $1 \mathrm{~h}$ and the plates incubated at $37^{\circ} \mathrm{C}$ at $5 \%$ $\mathrm{CO}_{2}$ and $\mathrm{O}_{2}$, to detach the cells. The cells were transferred onto Wallac glass fiber filter mats using a Tomtec cell harvester, and the beta emission counted using a Wallac Trilux Microbeta scintillation counter. $\mathrm{IC}_{50}$ values (mean and SEM) were calculated using SigmaPlot.

\section{WESTERN BLOT ANALYSIS}

Cells were plated in 6 well tissue culture plates (Falcon) at $2.5 \times 10^{5}$ cells per well and incubated overnight at $37^{\circ} \mathrm{C}$ at $5 \%$ $\mathrm{O}_{2}$ to allow the cells to attach. Drugs were added to the wells on the following day and the cells were harvested at the indicated time points using a lysis buffer containing phosphatase and protease inhibitors (Cheng et al., 2004). The protein concentration of cell lysates was determined using the bicinchoninic acid (BCA) assay and the lysates $(50 \mu \mathrm{g}$ of protein per well) were subjected to western blotting. The proteins were transferred to PVDF membranes and probed with antibodies for

Table 1 | BRAF and NRAS sequencing primers.

\begin{tabular}{|c|c|c|c|c|}
\hline Gene and exon & Primers & Primer sequence & Amplicon size & Location on reference sequence \\
\hline BRAF exon 11 & Reverse & Davies et al. (2002) & & $140481275-140481298$ \\
\hline & Reverse & TTTCAACAGGGTACACAGAACAT & & $140452668-140452690$ \\
\hline \multirow[t]{2}{*}{ NRAS exon 2} & Forward & ATTAATCCGGTGTTTTTGCGTTCT & $633 \mathrm{bp}$ & $115258944-115258921$ \\
\hline & Reverse & САTСTCTGAATCCTTTATСTCСАT & & $115258311-115258334$ \\
\hline NRAS exon 3 & Reverse & GGTTCCAAGTCATTCCCAGTA & & $115256172-115256192$ \\
\hline
\end{tabular}

The reference sequences cited are NC_000007.13 (BRAF) and NC_000001.10 (NRAS). 
Table 2 | Genetic and IC 50 data for NZM cell lines.

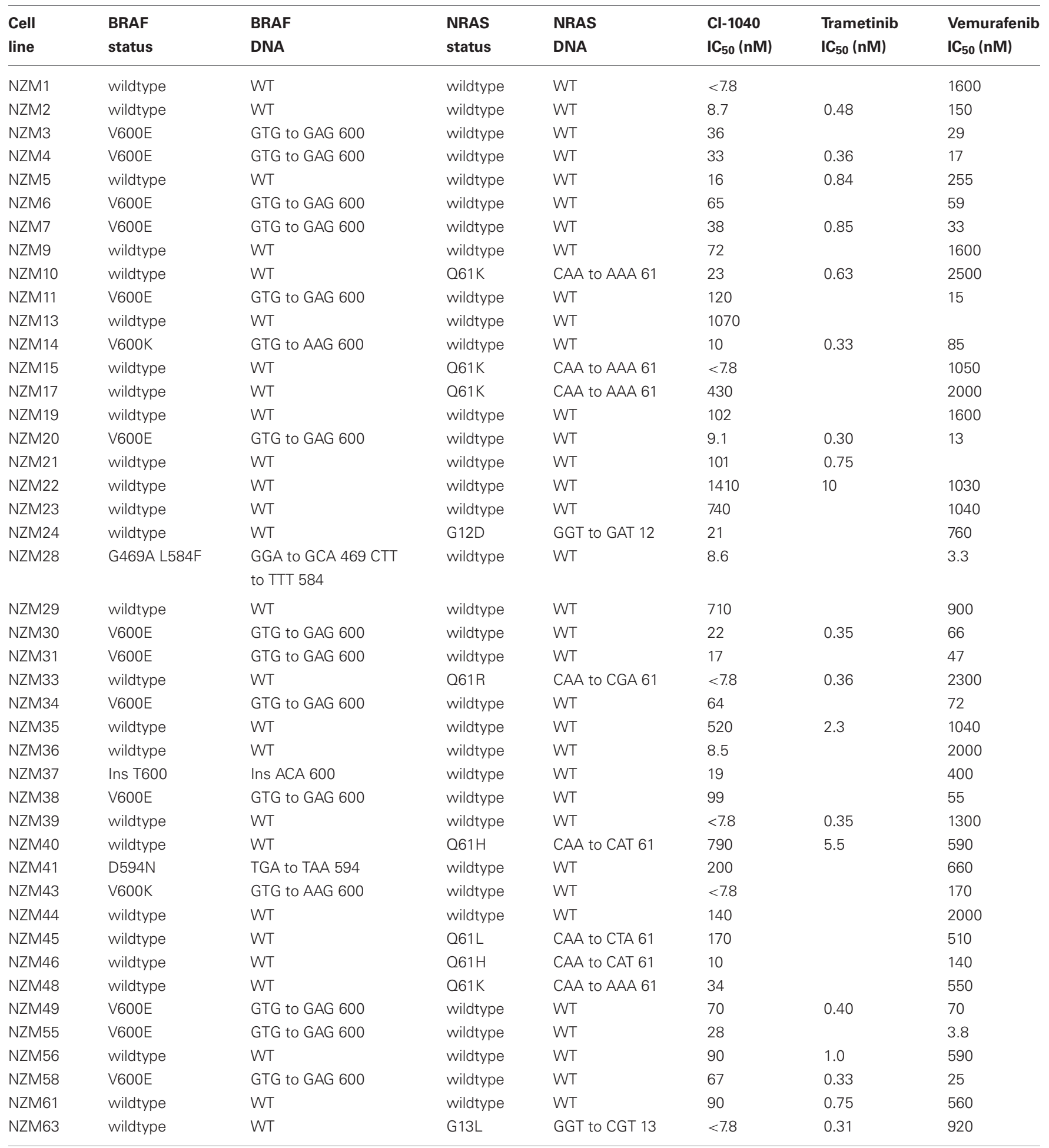

p-ERK, total ERK, p-MEK, total MEK, p-AKT, total AKT, cyclin D1 (all from Cell Signaling Technology), tubulin (Sigma) and $\beta$-actin (Millipore). The western blots were photographed using a LAS3000 Luminescent Image Analyzer (Fuji), and quantified using Image J software.

\section{RESULTS}

BRAF AND NRAS MUTATIONS IN MELANOMA CELL LINES

Screening results for the 44 melanoma cell lines are shown in Table 2. Thirteen lines (30\%) had activating V600E and another 2 lines (5\%) had activating V600K mutations. The NZM28 line 
contained a L584F amino acid substitution as well as a G469A substitution, the NZM41 line contained a D594N mutation, and the NZM37 had a Thr600ins mutation. The cell lines were also evaluated for mutations of the NRAS gene; four lines (9\%) had a Q61K mutation, one a G12D mutation, one a G13L mutation, two a Q61H mutation, and one a Q61R mutation. All the identified mutations are described in the Welcome Trust COSMIC DNA mutation database.

\section{SENSITIVITY OF MELANOMA LINES TO CI-1040, VEMURAFENIB AND TRAMETINIB}

The response of the melanoma cell lines to the MEK and BRAF inhibitors was tested using $\mathrm{IC}_{50}$ assays and the results are shown in Table 2 and Figure 1. The main study, with CI-1040 (Figure 1A), showed a clustering of low $\mathrm{IC}_{50}$ values for CI-1040 and vemurafenib for cell lines with activating BRAF mutations (V600E and V600K). The NZM28 cell line, which contained both G469A and L584F substitutions was very sensitive to both inhibitors and thus fell into this cluster. On the other hand NZM37, with a Thr600 insertion, and NZM41, with a D594N substitution, were relatively insensitive to vemurafenib (Table 2). Lines with NRAS mutations (Q61K, G12D, Q61H, and Q61R) were all resistant to vemurafenib and there was no correlation between the presence of mutation and sensitivity to CI-1040. A smaller study (Figure 1B) compared cell line sensitivity to trametinib. IC 50 values for trametinib were highly correlated with those for CI1040 ( $r=0.985$ ) but trametinib was, on average, more than 100fold more potent. Clustering of $\mathrm{IC}_{50}$ values was again observed, with all vemurafenib sensitive lines also showing sensitivity to trametinib.

\section{MODULATION OF ERK PHOSPHORYLATION IN RESPONSE TO MEK AND BRAF INHIBITORS}

In order to compare signaling changes in the ERK pathway to inhibition of proliferation, we measured changes to ERK phosphorylation induced by CI-1040, trametinib, and vemurafenib in NZM22, which is NRAS and BRAF wildtype and relatively resistant to all three inhibitors (Table 2), and in NZM4, which is BRAF mutant and relatively sensitive to the three inhibitors tested. ERK phosphorylation was more sensitive in NZM4 cells than in NZM22 cells in response to both CI-1040 and vemurafenib at both the 1-h and 24-h time points (Figure 2). Comparison of sensitivity to trametinib was also carried out but both cell lines were sensitive to the lowest drug concentration used.

ERK phosphorylation in response to CI-1040 was measured for NZM41, which is moderately resistant $\left(\mathrm{IC}_{50}=200 \mathrm{nM}\right)$. The phosphorylation status of MEK, which phosphorylates and

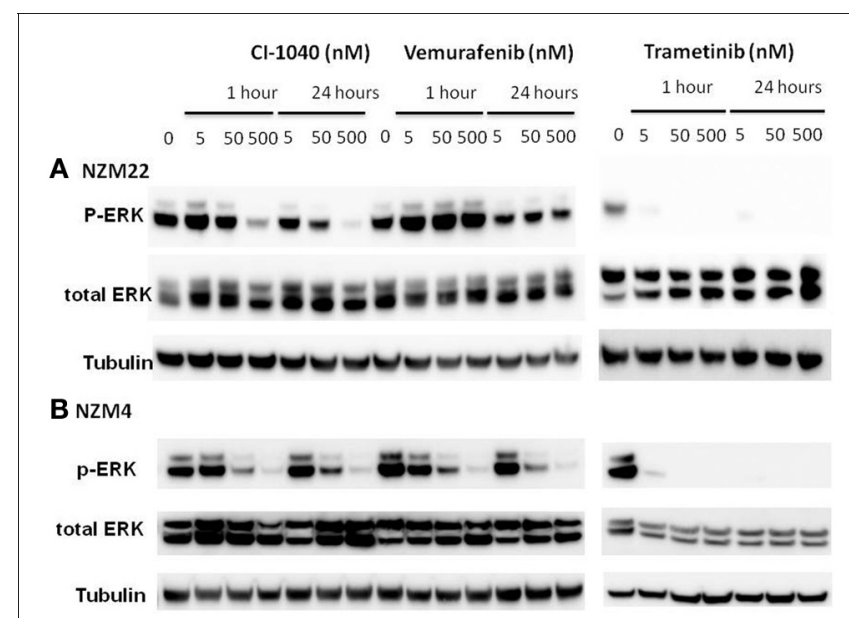

FIGURE 2 | Western blots showing changes in ERK phosphorylation 1 and $24 \mathrm{~h}$ after addition of different concentrations of the MEK inhibitors $\mathrm{Cl}-1040$ and trametinib, and the mutant BRAF inhibitor vemurafenib. (A) NZM22 line (BRAF wild type). (B) NZM4 line (V600E BRAF).

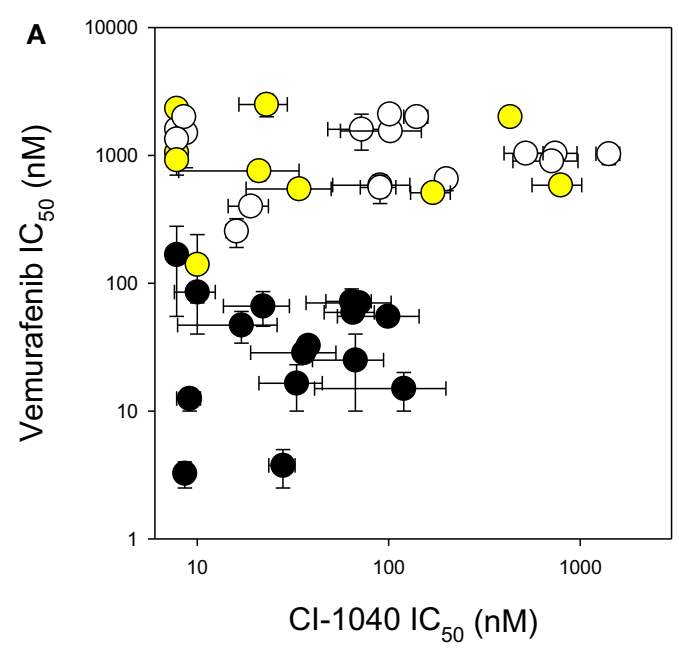

FIGURE 1 | Comparison of $\mathrm{IC}_{50}$ values for (A) Cl-1040 vs. vemurafenib and (B) trametinib vs. vemurafenib using a panel of melanoma cell lines. Black circles: mutant BRAF. Yellow circles: mutant NRAS. White circles:

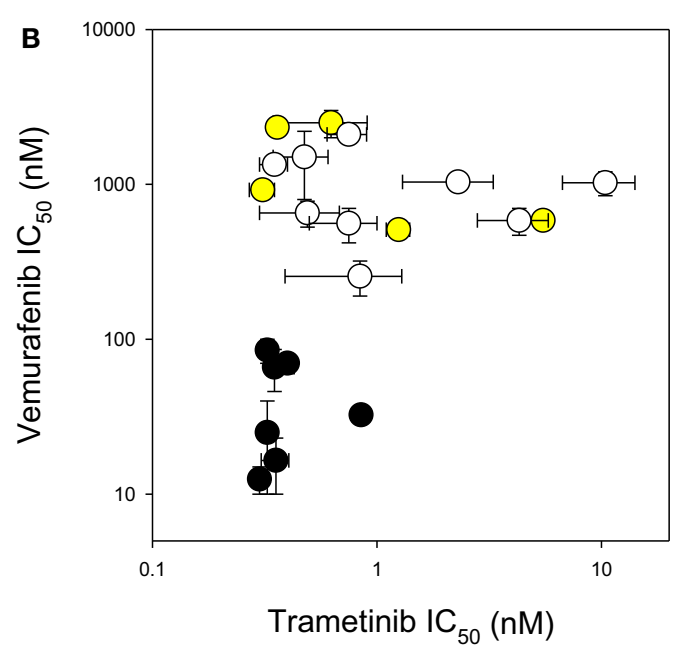

wildtype for BRAF and NRAS. Vertical and horizontal bars indicate the standard errors of the means where available; $I_{50}$ values of $<7.8 \mathrm{nM}$ are shown as $7.8 \mathrm{nM}$. 


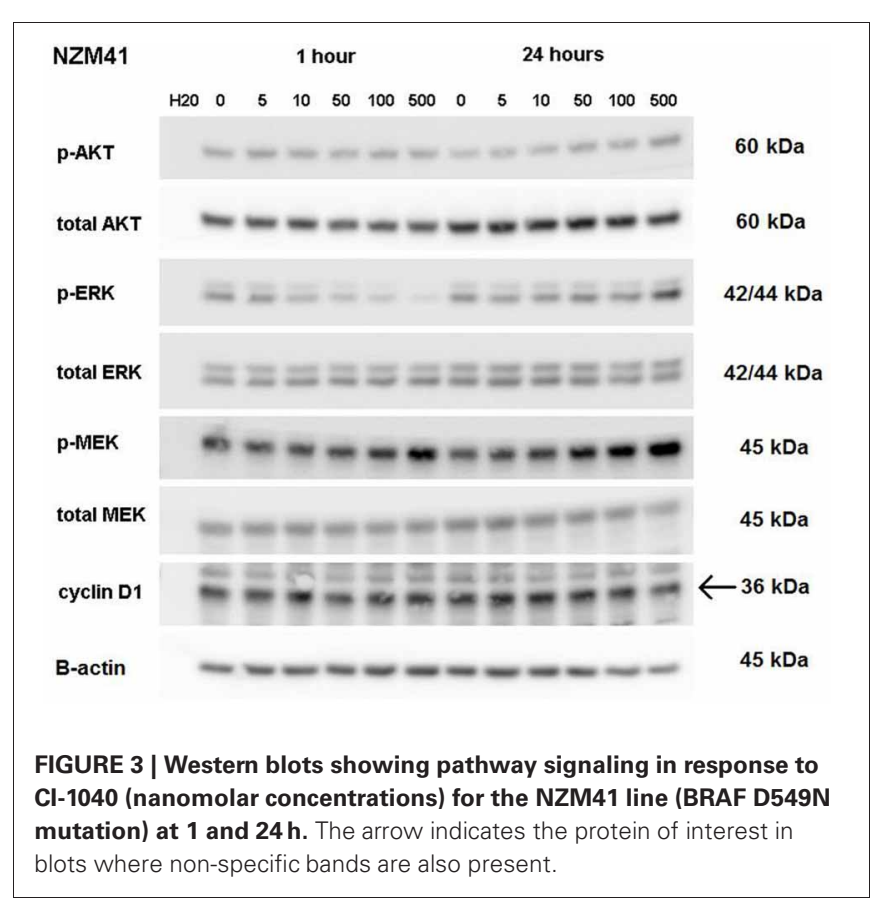

activates ERK, was measured for comparison. Since expression of cyclin D1 has been reported to be down-regulated following MEK inhibition in cells with BRAF V600E mutations (Pritchard et al., 2007), expression of cyclin D1 was also measured, but there was no change in expression. ERK phosphorylation was inhibited at a CI-1040 concentration of $10 \mathrm{nM}$ after $1 \mathrm{~h}$ but was comparatively unaffected after $24 \mathrm{~h}$, even at $500 \mathrm{nM}$ (Figure 3). This is in agreement with a report that sensitivity to a MEK inhibitor may decrease with exposure time (Friday et al., 2008). Interestingly, NZM41 showed evidence of CI-1040 resistance since MEK phosphorylation was increased following exposure to CI-1040 at $500 \mathrm{nM}$ after $1 \mathrm{~h}$ and even at $50 \mathrm{nM}$ after $24 \mathrm{~h}$ (Figure 3 ). The experiment was repeated with the NZM2 line, which is sensitive to CI-1040 $\left(\mathrm{IC}_{50}=8.7 \mathrm{nM}\right)$ and wildtype for BRAF and NRAS. ERK phosphorylation was highly sensitive to CI-1040 at both the 1-h and 24-h time points (Figure 4). No changes in MEK phosphorylation was observed but a decrease in cyclin D1 expression was apparent after $24 \mathrm{~h}$.

\section{DISCUSSION}

New Zealand has a high incidence of melanoma and it was therefore of interest to compare the frequencies of activating BRAF and NRAS mutations in New Zealand-derived melanoma lines with published values. The BRAF V600E mutation frequently observed was found in this study at 30\% (Table 2), lower than that reported by other groups (Davies et al., 2002; Houben et al., 2004; Edlundh-Rose et al., 2006; Thomas et al., 2007) while that for $\mathrm{V} 600 \mathrm{~K}$ was $5 \%$. The mutation frequency for NRAS was 23\% (Table 2), within the range reported by other groups (Davies et al., 2002; Houben et al., 2004; Edlundh-Rose et al., 2006; Thomas et al., 2007). The data in Figure 1 and Table 2 clearly show that cell lines with activating V600E and V600K mutations were generally sensitive to CI-1040, trametinib and vemurafenib

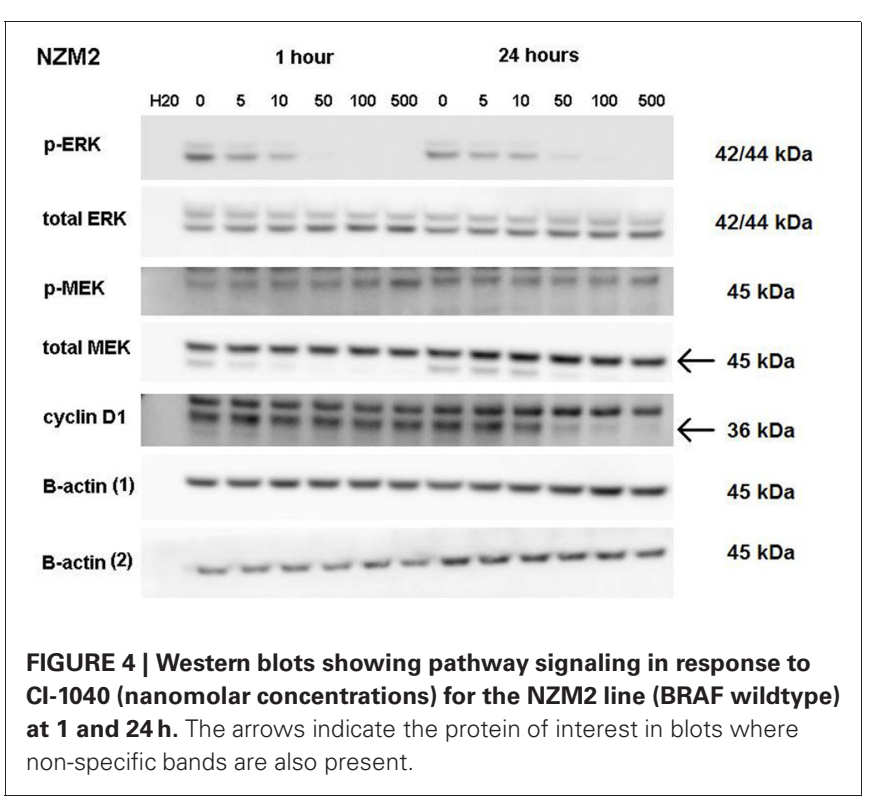

inhibition. As shown in Table 2 the NZM28 cell line, which contained both G469A and L584F substitutions, was very sensitive to both inhibitors. SIFT algorithm analysis (Kumar et al., 2009) was undertaken to provide an indication of the effect of mutation, and predicted that the $\mathrm{L} 584 \mathrm{~F}$ mutation alters protein function, consistent with this effect. On the other hand NZM37, with a Thr600 insertion and NZM41, with a D594N substitution, were relatively insensitive to vemurafenib (Table 2), raising the question of why they might be selected for during melanoma development. The G469A mutation has been reported to have no enhancing effect on BRAF (Smalley and Flaherty, 2009) but it has been reported that kinase-dead BRAF mutations of D594 can have an indirect effect on tumor progression by enhancing CRAF activity (Heidorn et al., 2010). Several other studies have explored the relationship between mutation status and sensitivity to MEK inhibition for a variety of tumor types including melanoma, breast, ovarian, and lung cancers (Davies et al., 2002; Solit et al., 2006). In these studies, cell lines with BRAF mutations were very sensitive to MEK inhibition of cell growth while cell lines with NRAS mutations showed a range of sensitivities, in agreement with the present results.

It has been reported that either PI3K oncogenic mutations or deletion of PTEN reduces sensitivity of cells to MEK inhibitors (Wee et al., 2009). In this study, the NZM40 and NZM46 lines were found to have an activated mutated PI3K enzyme and the NZM6, NZM30, NZM34, and NZM43 lines were found to lack PTEN expression (Kim et al., 2012). However, there was no clear indication of altered sensitivity to CI-1040 among these cell lines. There are also reports that up-regulation of MEK can lead to reduced sensitivity of cells to MEK inhibitors (Friday et al., 2008). We investigated ERK phosphorylation in a number of melanoma lines (Figures 2-4). Although some evidence of loss of initial sensitivity in resistant lines was found (Figure 3 ) the pattern of phosphorylation results broadly followed that of the $\mathrm{IC}_{50}$ results.

In conclusion, we have assessed the responses of a series of 44 melanoma lines, generally of low passage number, to CI-1040, 
a prototypic MEK inhibitor, as well as to trametinib, a clinical MEK inhibitor and vemurafenib, a clinical BRAF inhibitor. We identified a sub-set of 16 lines (36\%) with activating BRAF mutations (Figure 1) that showed sensitivity to both clinical inhibitors, supporting the hypothesis that a combination of both BRAF and MEK inhibitors might have advantages over either drug alone because of potentially synergistic inhibitory effects on signal transduction. We also identified a second sub-set of 10 cell lines $(23 \%)$ that were resistant to vemurafenib but sensitive to a MEK inhibitor. Some but not all of these cell lines exhibited

\section{REFERENCES}

Charters, G. A., Stones, C. J., Shelling, A. N., Baguley, B. C., and Finlay, G. J. (2011). Centrosomal dysregulation in human metastatic melanoma cell lines. Cancer Genet. 204, 477-485.

Cheng, S. W., Fryer, L. G., Carling, D., and Shepherd, P. R. (2004). Thr2446 is a novel mammalian target of rapamycin (mTOR) phosphorylation site regulated by nutrient status. J. Biol. Chem. 279, 15719-15722.

Coory, M., Baade, P., Aitken, J., Smithers, M., McLeod, G. R., and Ring, I. (2006). Trends for in situ and invasive melanoma in Queensland, Australia, 1982-2002. Cancer Causes Control 17, 21-27.

Davies, H., Bignell, G. R., Cox, C., Stephens, P., Edkins, S., Clegg, S., et al. (2002). Mutations of the BRAF gene in human cancer. Nature 417, 949-954.

Edlundh-Rose, E., Egyhazi, S., Omholt, K., Mansson-Brahme, E., Platz, A., Hansson, J., et al. (2006). NRAS and BRAF mutations in melanoma tumours in relation to clinical characteristics: a study based on mutation screening by pyrosequencing. Melanoma Res. 16, 471-478.

Falchook, G. S., Lewis, K. D., Infante, J. R., Gordon, M. S., Vogelzang, N. J., DeMarini, D. J., et al. (2012). Activity of the oral MEK inhibitor trametinib in patients with advanced melanoma: a phase 1 dose-escalation trial. Lancet Oncol. 13, 782-789.

Flaherty, K. T., Puzanov, I., Kim, K. B., Ribas, A., McArthur, G. A., Sosman, J. A., et al. (2010). Inhibition of mutated, activated BRAF in metastatic melanoma. N. Engl. J. Med. 363, 809-819.
Flaherty, K. T., Robert, C., Hersey, P., Nathan, P., Garbe, C., Milhem, M., et al. (2012). Improved survival with MEK inhibition in BRAF-mutated melanoma. N. Engl. J. Med. 367, 107-114.

Friday, B. B., Yu, C., Dy, G. K., Smith, P. D., Wang, L., Thibodeau, S. N., et al. (2008). BRAF V600E disrupts AZD6244-induced abrogation of negative feedback pathways between extracellular signalregulated kinase and Raf proteins. Cancer Res. 68, 6145-6153.

Hatzivassiliou, G., Liu, B., O’Brien, C., Spoerke, J. M., Hoeflich, K. P., Haverty, P. M., et al. (2012). ERK inhibition overcomes acquired resistance to MEK inhibitors. Mol. Cancer Ther. 11, 1143-1154.

Heidorn, S. J., Milagre, C., Whittaker, S., Nourry, A., Niculescu-Duvas, I., Dhomen, N., et al. (2010). Kinase-dead BRAF and oncogenic RAS cooperate to drive tumor progression through CRAF. Cell 140, 209-221.

Houben, R., Becker, J. C., Kappel, A., Terheyden, P., Brocker, E. B., Goetz, R., et al. (2004). Constitutive activation of the Ras-Raf signaling pathway in metastatic melanoma is associated with poor prognosis. J. Carcinog. 3, 6.

Johannessen, C. M., Boehm, J. S., Kim, S. Y., Thomas, S. R., Wardwell, L., Johnson, L. A., et al. (2010). COT drives resistance to RAF inhibition through MAP kinase pathway reactivation. Nature 468, 968-972.

Kim, J. E., Stones, C., Joseph, W. R., Leung, E., Finlay, G. J., Shelling, A. N., et al. (2012). Comparison of growth factor signalling pathway utilisation in cultured normal melanocytes and melanoma cell lines. BMC Cancer 12:141. doi: 10.1186/1471-2407-12-141

NRAS mutations, suggesting that some melanomas that are wildtype for both BRAF and NRAS may respond to trametinib, a MEK inhibitor. If this applies in vivo, then a proportion of melanoma patients whose disease is resistant to BRAF inhibitor therapy may respond to therapy with a MEK inhibitor.

\section{ACKNOWLEDGMENTS}

This study was supported by doctoral scholarship funding from the Auckland Medical Research Foundation and from the Genesis Oncology Trust, and by the Auckland Cancer Society.

Kumar, P., Henikoff, S., and Ng, P. C. (2009). Predicting the effects of coding non-synonymous variants on protein function using the SIFT algorithm. Nat. Protoc. 4 1073-1081.

Liang, J. J., Robinson, E., and Martin, R. C. (2010). Cutaneous melanoma in New Zealand: 2000-2004. ANZ J. Surg. 80, 312-316.

Lis, J. T., and Schleif, R. (1975). Size fractionation of doublestranded DNA by precipitation with polyethylene glycol. Nucleic Acids Res. 2, 383-389.

Marshall, E. S., Finlay, G. J., Matthews, J. H., Shaw, J. H., Nixon, J., and Baguley, B. C. (1992). Microculturebased chemosensitivity testing: a feasibility study comparing freshly explanted human melanoma cells with human melanoma cell lines. J. Natl. Cancer Inst. 84, 340-345.

Marshall, E. S., Matthews, J. H. Shaw, J. H., Nixon, J., Tumewu, P., Finlay, G. J., et al. (1994). Radiosensitivity of new and established human melanoma cell lines: comparison of $[3 \mathrm{H}]$ thymidine incorporation and soft agar clonogenic assays. Eur. J. Cancer 30A, 1370-1376.

Pritchard, C., Carragher, L., Aldridge, V., Giblett, S., Jin, H., Foster, C., et al. (2007). Mouse models for BRAF-induced cancers. Biochem. Soc. Trans. 35, 1329-1333.

Sebolt-Leopold, J. S. (2004). MEK inhibitors: a therapeutic approach to targeting the Ras-MAP kinase pathway in tumors. Curr. Pharm. Des. 10, 1907-1914.

Smalley, K. S., and Flaherty, K. T. (2009). Integrating BRAF/MEK inhibitors into combination therapy for melanoma. Br. J. Cancer 100, 431-435.
Solit, D. B., Garraway, L. A., Pratilas, C. A., Sawai, A., Getz, G., Basso, A., et al. (2006). BRAF mutation predicts sensitivity to MEK inhibition. Nature 439, 358-362.

Thomas, R. K., Baker, A. C., Debiasi, R. M., Winckler, W., Laframboise, T., Lin, W. M., et al. (2007). High-throughput oncogene mutation profiling in human cancer. Nat. Genet. 39, 347-351.

Wee, S., Jagani, Z., Xiang, K. X., Loo, A., Dorsch, M., Yao, Y. M., et al. (2009). PI3K pathway activation mediates resistance to MEK inhibitors in KRAS mutant cancers. Cancer Res. 69, 4286-4293.

Conflict of Interest Statement: The authors declare that the research was conducted in the absence of any commercial or financial relationships that could be construed as a potential conflict of interest.

Received: 30 January 2013; accepted: 09 April 2013; published online: 08 May 2013.

Citation: Stones CJ, Kim JE, Joseph WR, Leung E, Marshall ES, Finlay GJ, Shelling $A N$ and Baguley BC (2013) Comparison of responses of human melanoma cell lines to MEK and BRAF inhibitors. Front. Genet. 4:66. doi: 10.3389/fgene. 2013.00066

This article was submitted to Frontiers in Cancer Genetics, a specialty of Frontiers in Genetics.

Copyright (c) 2013 Stones, Kim, Joseph, Leung, Marshall, Finlay, Shelling and Baguley. This is an open-access article distributed under the terms of the Creative Commons Attribution License, which permits use, distribution and reproduction in other forums, provided the original authors and source are credited and subject to any copyright notices concerning any third-party graphics etc. 